\title{
The Financial Logic of Internet Platforms: The Turnover Time of Money at the Limit of Zero
}

\author{
Marcos Dantas \\ Communication School, Federal University of Rio de Janeiro, Brazil, \\ mdantas@inventhar.com.br, www.marcosdantas.pro.br
}

\begin{abstract}
In the first two sections of Capital, Volume 2, Marx examines the factors that pressure capital to reduce its circulation and turnover times at the limit of zero. By doing so, he shines a light on the role played by transportation and communications industries in the accumulation process and the reasons that these sectors are important frontiers of productive capital investment and surplus value extraction. This article suggests how the Internet's socialdigital platforms, such as Google, Facebook, Amazon and Airbnb, work according to the logic expounded by Marx, thus generating extraordinary profits for financial capital. Also, because of this Marxian logic, the main source of these huge platforms' profits is the informational work done by millions of people who access these websites to engage in recreational activities or to meet the demands for goods and services in a Society of the Spectacle (Debord) subsumed into commodity fetishism.
\end{abstract}

Keywords: capital turnover, unpaid work, surplus-value, socio-digital platforms, financial capital.

Acknowledgement: The author thanks Gabriela Raulino, Nahema Barra de Oliveira, Rafael Evangelista, Sergio Amadeu and Tiago Tadeu for their comments and suggestions. Thanks also to the reviewers for their challenging comments.

\section{Introduction}

It is equally a tendency of capital to make human labour (relatively) superfluous, so as to drive it, as human labour, towards infinity (Marx 1973/1939).

Socio-digital platforms (SDPs), such as Alphabet/Google, Facebook, Amazon and similar websites, are physical and logical infrastructures for processing and communicating information that allow two or more users to interact directly with each other, whether these interactions are recreational, professional or commercial. These users may be buyers or sellers of goods and services, marketing advertisers, software developers or, for the most part, just ordinary people exchanging messages with other ordinary people about everyday issues or engaging in leisure activities to occupy their free time.

Despite their apparent differences, 'social networks' or 'social media' such as YouTube or Facebook, search engines like Google, audio-visual services like Netflix or large 'virtual' stores such as Amazon, Alibaba or e-Bay are all similar in substance: they work as huge marketplaces, a 'place' where buyers and sellers of goods and services meet for direct negotiations on their supply and demand conditions. Those SDPs obtain their revenues and profits mainly from the monetisation of data extracted from their users, these users being 'consumers', 'advertisers', goods or service 'sellers' and so on. From this central hypothesis, this article will be an attempt to understand the financial-economic logic that commands the capitalist process of accumulation in 
the SDPs, looking at their processes of user data extraction and monetisation going beyond their media or shopping appearances. We will also see how this process could be linked to the whole capital accumulation process.

The theoretical and methodological orientation of this article comes from Karl Marx's critical theory, so the main reference will be Capital, especially Volume II (Marx 1956/1885). Our aim is to demonstrate how the logic of capitalist accumulation that presides over the scene of SDPs can be investigated from the role played by communications in the development of capitalism, as suggested by Marx. As we know, this is a debate that was opened in the Marxian field by Dallas Smythe (1977), for whom the "audience" is the product-value exchanged between the media and its advertising market and also the labour that produces that value. Since then, several authors have been discussing, improving, revising or even denying this hypothesis (Huet et al. 1978; Jhally and Livant 1986; Zallo 1988; Garnham 1990; Maxwell 1991; Chen 2003; Caraway 2011; Fuchs 2012a; 2012b; Arvidsson and Colleoni 2012).

However, the primary aim of this article is not to review this so-called 'blindspot debate', albeit it may add some new insights to it. As we will see, the primary aim is supported by Marx's investigations on the processes of value realisation discussed mainly in Capital: Volume II, whereas the 'blindspot debate' is essentially based on the logic of value production, as explained by Marx in Capital: Volume I. It also focuses mainly on the mass media advertising-driven industries rather than the whole process of capital accumulation through the communication industries. Marx, in Capital: Volume II, shows how circulation and turnover processes affect the rates of surplusvalue and, consequently, profit and accumulation. To shorten the times of circulation, turnover and realisation of investments, since the 19th century capital has been developing means of communication and transportation, from telegraphy and steam locomotives to present-day Internet. In the meantime, it has built upon these technologies new powerful industries, including mass media, capable of leveraging and accumulating capital while also culturally and ideologically moulding capitalist society. The first two parts of this article will revisit, expose and discuss Marx's theory on the economic role of communications in capitalism. The third part will examine how socio-digital platforms work economically and, hence, how they produce value (a lot of value!) for capital.

\section{Capital Turnover}

In Capital: Volume I, Marx essentially addresses the production of surplus-value in the industrial economy. The theory is well known: the worker sells his labour-power for a wage that meets his subsistence needs, but is obliged to work for free for a longer period of time than that necessary to earn that wage. From this unpaid labour time, the capitalist extracts the surplus-value of the commodity, and this is where his profit comes from.

It so happens that, once the commodity has been produced, the capitalist still needs to take it to market, sell it, and receive back the invested money plus the added surplusvalue. Before this circuit is completed, the surplus-value produced is only potential. If the commodity, for any reason, is not sold, the surplus-value will be zero for all practical purposes. And these purposes are many; after all, the entrepreneur is committed to his or her suppliers, still has to pay wages and needs some money to pay for his or her own personal expenses. Thus, realising the surplus-value produced is just as important as producing surplus-value. Without that, there will be no surplus-value.

The total movement of capital along the stages of production and sale of commodities constitutes the general process of circulation, presented in Formula 1 
below, from the original by Marx $(1956 / 1885,15)$ : money $(M)$ is advanced to buy means of production and labour-power $(C)$ that, in the production circuit $(P)$, will be transformed into new and valued commodity $(\Delta C)$ to be sold and turned into surplusmoney $(\Delta M)$ :

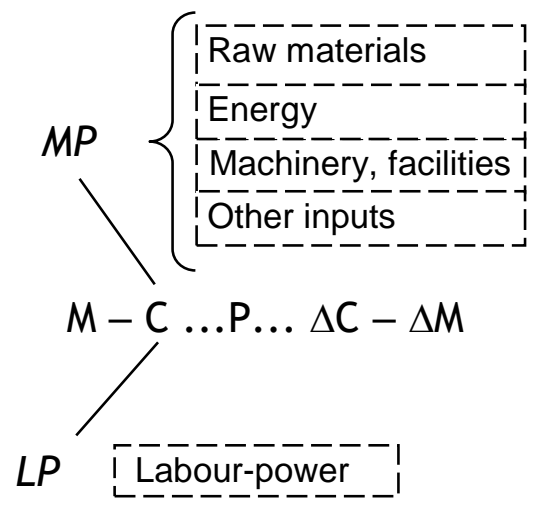

Formula 1

Circulation is a customary process for any firm (or "individual capitalist", in Marx's words). At the same time, it is linked to a vast circulatory network that articulates other firms, economic sectors, and the economy as a whole, each level affecting and being affected by the others. In this process, each level withdraws money and production factors from other levels, returning them to these other levels later on. At first, the process must pursue equilibrium. However, by the very nature of capital, starting with the original imbalance of surplus-value, these links will result in a large system far from equilibrium. ${ }^{1}$ Hence, their constant crises.

Formula 1 can take on the configuration in Formula 2:

${ }^{1}$ This is truly the thermodynamics-of-equilibrium reasoning that we must bear in mind to really understand Marx's thinking: the circuit of capital seeks equilibrium, although it is unbalanced from its foundations because of the non-equilibrium between the use value and exchange value of labour power (source of plus-value) and also because of the unbalanced turnover times among the different sectors of the economy. We can say that Marx was the first thinker to describe a system far from the equilibrium (without realising it, of course), a concept that would be developed by physicists only in the second half of the 20th century. But to Marx's dialectic this was the natural condition of the movement of history, a "law of Nature". 


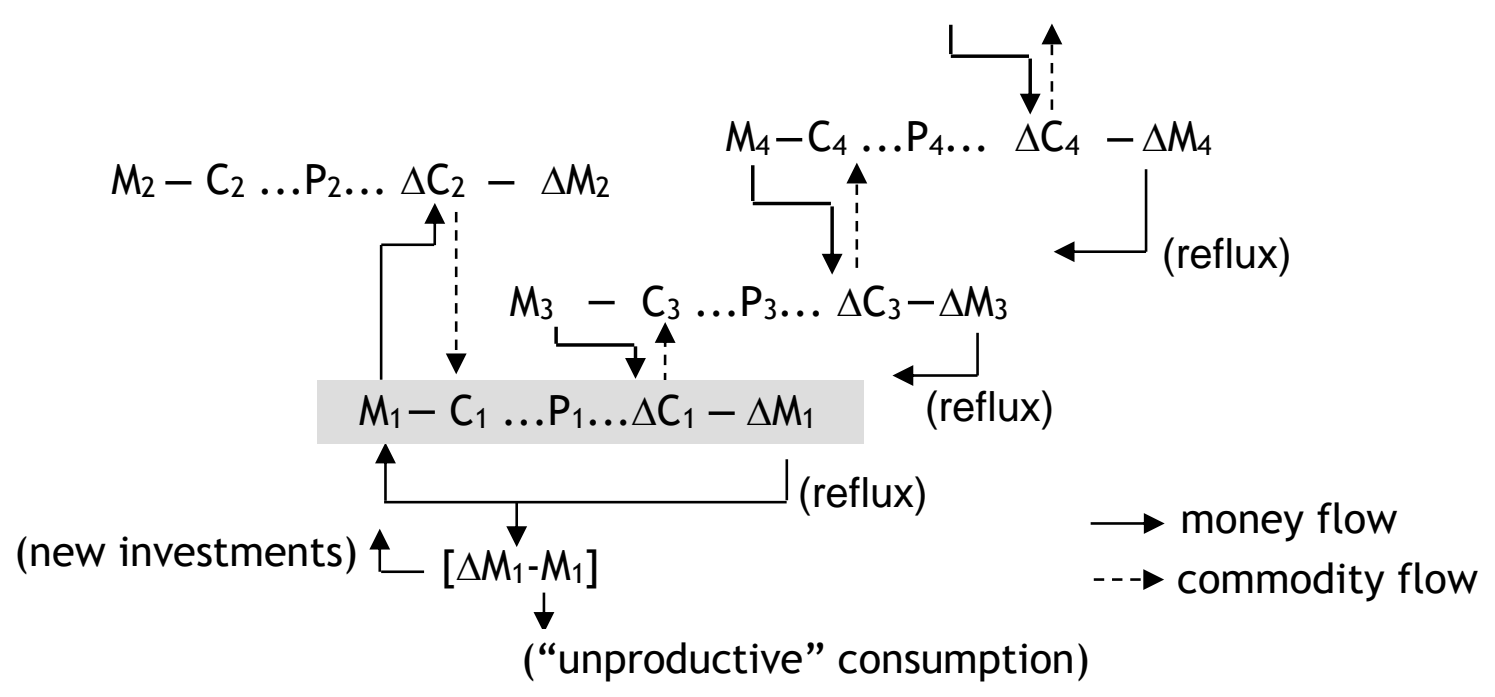

Formula 2

The dashed arrow $\Delta \mathrm{C}_{2} \rightarrow \mathrm{C}_{1}$ indicates that the money $M_{1}$ procured commodities from circuits generally defined by $M_{2} \ldots \Delta M_{2}$ (another firm, another economic segment), to produce and sell valued commodities to circuits defined by $M_{3}, M_{4}$, etc. Naturally, if commodities leave, money enters, or vice versa. In each circulation, $\Delta \mathrm{M}_{1}$ will be reemployed in the purchase of new commodities to keep the production flow and the maintenance of machinery and facilities. Necessarily, the sum of money originally invested $\left(M_{1}\right)$ will have to be replaced, but the difference in surplus value $\left(\Delta M_{1}-M_{1}\right)$ may be applied to expand the business (new investments) or in 'shareholder remuneration' (fees, dividends, bonuses, etc.). This 'remuneration' will be used in capitalist consumption or financial speculation ('unproductive' consumption), or even in other business investments.

In the total movement of circulation, the valorisation of capital will be a function not only of production but also of factors determined by turnover time (Figure 1), as examined by Marx mainly in Sections 1 and 2 of Volume II. This time is the sum of the times of production $\left(t_{p}\right)$ and realisation $\left(t_{r}\right)$ of the commodity, that is, its reconversion into money and the return ("reflux") of the money into the entrepreneur's pockets. In turnover, two circuits cross: the money circuit and the product circuit. The money circuit begins with the procurement or payment of the production factors and ends with its return. The product circuit begins when the factors enter into production processes and ends when a new use value, with added surplus-value, returns to circulation, until its final realisation. ${ }^{2}$

${ }^{2}$ In Part I of Volume 2, Marx describes three circuits of capital: money-capital (M - C ...P... $\Delta \mathrm{C}-\Delta \mathrm{M})$, productive-capital $(\mathrm{P} \ldots \Delta \mathrm{C}-\Delta \mathrm{M}-\mathrm{C} \ldots \mathrm{P})$ and commodity-capital $(\Delta \mathrm{C}-\Delta \mathrm{M}-\mathrm{C} \ldots$ $\mathrm{P} \ldots \Delta \mathrm{C}$ ). Because this third circuit starts and ends in $\Delta \mathrm{C}$, Marx investigates it in his famous "reproductions schemes" (Part 3 of Volume II). The two others, for Marx, are mainly capital turnover issues, thus investigated by him in Part 2. 


\subsection{First Determination: Money Advance}

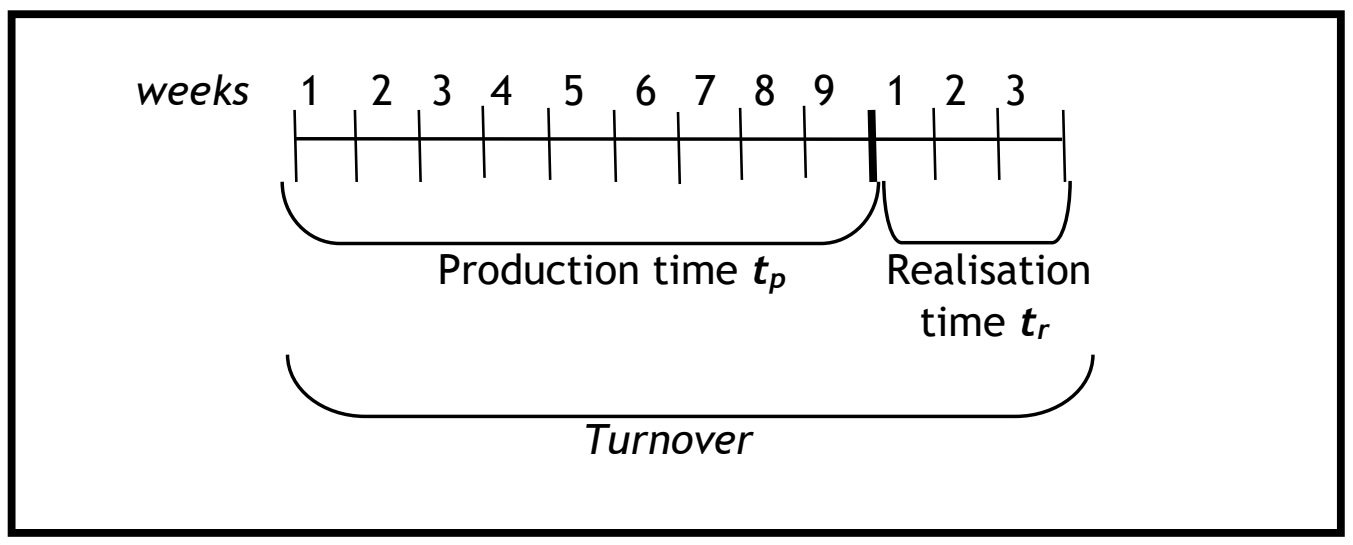

Figure 1: Turnover time

Marx comments that, throughout turnover, there will be a discrepancy between money and production circuits and, for as long as realisation is not complete and money does not flow back, the entrepreneur could run out of resources to maintain production flow. If this does not happen it is because the entrepreneur may have an initial volume of money greater than what was directly applied.

Suppose (following Marx's exercises) that production lasts nine weeks and the sale of the commodities produced, with return of $\Delta \mathrm{M}$, is completed in three weeks (Figure 1). For three weeks, the entrepreneur would be unable to buy back raw materials and supplies, or to pay weekly wages. To cover this lapse of time, he will need to have his own savings or resort to the credit market. In Part 2 of Capital: Volume II, Marx indicates here and there that credit will play a very important role in this circuit, but will only be studied in detail in Volume III.

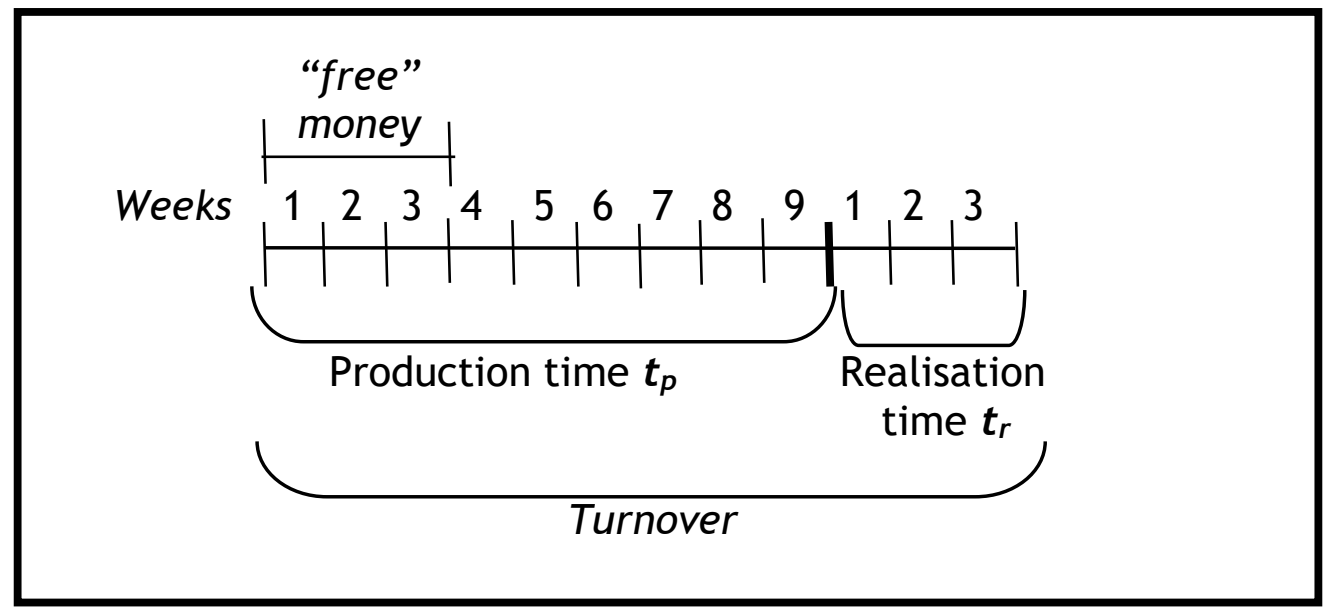

Figure 2: The money circuit

Therefore, the money needed to open an entire production circuit should cover investments and expenses corresponding to twelve weeks, not nine. On the other hand, for the same reason, when all the money realised in circulation is returned, it will not have to be spent on costs corresponding to nine weeks of production because, out 
of those, three weeks were financed by that "free" money. The returned surplus-money can only be used for investments and expenses corresponding to the remaining six weeks of work (Figure 2), leaving a "free" portion corresponding to three weeks. In the next turnover, the "free" portion will correspond to three more weeks beyond the initial three and, after a few turnovers, all the money initially invested, including the initial extra, will have been fully recovered. So, with each turnover, the result will be the accumulation of "free" money: capital producing capital. Marx, in exercises that are hermetic even for contemporary commentators and rarely explored in Marxist literature, ${ }^{3}$ was discovering the remote origins of the financialisation of capital. ${ }^{4}$

\subsection{Second Determination: Different Annual Rates of Surplus-Value}

Based on the first determination, different economic sectors will have different times of variable capital turnover and, therefore, different annual rates of surplus-value, since the profit rate is a function of the surplus-value rate.

Consider Business $A$. Production time is equal to four weeks, realisation time is equal to one week: total turnover is five weeks. The quantity of turnovers in a year is equal to 10. The initial investment is $€ 25,000.00$, of which $€ 5,000.00$ is in variable capital. The surplus-value rate is equal to $100 \%$. At the end of one year, the variable capital realised will be $€ 50,000(5,000 \times 10)$ and the annual sum of surplus-value will also be $€ 50,000$. Given the advanced variable capital $(€ 5,000)$, the annual rate of surplus-value will be $1,000 \%$.

Consider Business $B$. Let us keep all conditions of the previous example, except for a working time equal to turnover time in one year (50 weeks) and immediate realisation time. ${ }^{5}$ The advance then is divided equally for all 50 weeks of the year. After one year, the variable capital realised will be $€ 5,000(5,000 \times 1)$ and the sum of surplus-

${ }^{3}$ In his explanation on Part 2 of Volume II, in his A Companion to Marx's Capital, Volume II, David Harvey $(2013,287)$ begins by saying: "These three chapters are hard to understand and assess. I am still not sure how best to read them"; and continues to show explicit annoyance with the mathematical exercises developed therein by Marx. Harvey tends to underestimate the chapters. In fact, they are hard to read, and it seems that in the copious material edited by Engels for Volumes II and III, the drafts included in Part 2 of Volume II would be those in the roughest state. Engels may have edited calculations, hypothetical exercises by which Marx intended to clarify for himself certain work hypotheses. He might not even have published them, at least not as they were published, if he had edited the final text of these chapters himself. Examples of exercises or similar speculations that remained in his drafts, not included in Capital or added in more elaborate forms, can be found in Grundrisse, in manuscripts from 1861-1863, in Theories of Surplus-Value and in other texts. This does not make them less important. But perhaps this is how "best to read them": drafts that display strict theoretical logic, still valid but perhaps lacking better exposure, including the filling in or clarification of many gaps.

${ }^{4}$ These exercises, and the others that follow, with slight adaptations, are taken from Part 2 of Volume II of Capital, following Marx's reasoning and conclusions ipsis litteris. It should be noted, however, that Marx considers other variables and many other details, including fixed capital and constant capital effects, not presented here either due to length limitations or because they do not affect our basic hypotheses and conclusions.

5 "Although this case occurs in reality only as an accidental exception, it must serve as our point of departure in this investigation, because here relations shape themselves in the simplest and most intelligible way" (Marx 1956/1885, 162). But this could be the case, for instance, of capital goods industries that normally operate to order; thus its time of production (or work) is equal to the realisation. 
value will also be $€ 5,000$. Given the advanced variable capital $(€ 5,000)$, the annual rate of surplus-value will be $100 \%$.

To obtain an annual surplus-value rate as close as possible to $1,000 \%$, Business $B$ should advance for five weeks all the money that it would advance over 50 . That is, its production scale becomes the same as a large enterprise. Annual surplus-value rates in shorter turnover times work as a kind of attractor for the whole capitalist system: it moves in that direction, always aiming to speed up turnover or (which is the same) reduce turnover times in order to turn over the largest amount feasible of commodities in a year, thereby obtaining the highest surplus-value annual rates possible.

\subsection{Third Determination: Variable Capital Realisation}

Different turnover times in different sectors of the capitalist economy affect variable capital realisation times in different ways.

Once a wage of 500 pounds sterling is paid (Marx's example),

These $£ 500,[\ldots]$, have ceased to be capital. They are paid out in wages. The labourers in their turn pay them out in the purchase of means of subsistence, consuming means of subsistence worth $£ 500$. A quantity of commodities of that value is therefore annihilated; [...]. As far as concerns the labourer, this quantity of commodities has been consumed unproductively, except inasmuch as it preserves the efficacy of his labour-power, an instrument indispensable to the capitalist. (Marx 1956/1885, 188-189).

It is important here to underline the difference that Marx introduces between "productive" and "unproductive" consumption: the first is consumption within the productive process; the latter is the definitive final consumption of a commodity. The consumption of fabric in the production of trousers is "productive". The consumption of trousers by anyone will be "unproductive": it is consumption that definitively removes material from circulation and, over time, this material will be "annihilated" by the wear and tear of consumption. In Marx, as the process of producing value withdraws commodities from circulation, in the end it should put commodities back in circulation, keeping the systemic balance. The workers' "unproductive" consumption closes the circuit because it restores their physical and psychic energies to continue working. ${ }^{6}$

The turnover of variable capital (in the form of wages) will not be the same turnover of money and products, since the workers spend their wage procuring commodities before the circuits of money and product are finished. If turnover is five weeks but wages are paid weekly, the worker will already withdraw and "annihilate" commodities before his or her boss puts commodities back into circulation. If the salary is paid weekly but the turnover time is 50 weeks, the imbalance will be much higher. Whatever the turnover time, this imbalance will reflect directly in the production and realisation of value, as the capitalists will need to advance variable capital to honour their wage commitments before recovering the surplus-money $(\Delta \mathrm{M})$ that will cover these expenses. Value is being produced, part of it is already being realised by variable capital in the form of wages, but most of it still continues to move around in circulation. This does not quite meet the interests of the capital, much less of the "individual capitalist"...

${ }^{6}$ See Footnote 1. 
As we see above, these turnover-time determinations force the entrepreneurs to obtain money from the market or use their own funds to honour their commitments while the investment, including variable capital, is not realised. However, Marx concludes:

The shorter the period of turnover of capital - the shorter therefore the intervals at which it is reproduced throughout the year - the quicker is the variable portion of the capital, originally advanced by the capitalist in the form of money, transformed into the money-form of the value (including, besides, surplus-value) created by the labourer to replace this variable capital; the shorter is the time for which the capitalist must advance money out of his own funds, and the smaller is the capital advanced by him in general in proportion to the given scale of production; and the greater comparatively is the quantity of surplus-value which he extracts during the year with a given rate of surplus-value, because he can buy the labourer so much more frequently with the money-form of the value created by that labourer and can so much more frequently set his labour into motion again (Marx 1956/1885, 191).

In other words, if the wage already comes from an advanced circuit of accumulation in which the employed capital became the product of realised capital, the commodities acquired by that wage were paid with the commodities sold by the capitalist. That is, the capitalist stops buying labour-power with advanced capital and starts buying it with realised capital. The positive impact of this on the surplus-value rate is obvious: one more reason for capital to try to increase the number of turnovers per year by reducing as far as possible each turnover time.

\subsection{Fourth Determination: Money Supply}

According to Marx, in his time, if the capitalist system was in permanent expansion (or accumulation), then the monetary base that feeds the entire system should be in permanent expansion. For each circuit $M \ldots \Delta M$, exponentially multiplied by the increasingly gigantic dimension of the whole system (Formula 2), it will be necessary to provide more means of payment than before. The amount of money in circulation or in bank deposits - whether in the form of metal, paper money or securities - cannot stop growing. After developing a whole set of mathematical formulations about turnover, in which circuits always start with money and end with more money $(\Delta M)$, Marx asks: where does the money come from?

Let the circulating capital of $£ 500$ advanced in the form of money-capital, whatever its period of turnover, now stand for the total circulating capital of society, that is, of the capitalist class. Let the surplus-value be £100. How can the entire capitalist class manage to draw continually $£ 600$ out of circulation, when it continually throws only $£ 500$ into it? (Marx 1956/1885, 202).

As we know, in Marx's time, money in circulation should have been strongly backed by gold and silver deposits in central banks and other banking institutions. Marx, then, at this stage of his formulations, starts examining the production of gold (or silver) as a direct production of money.

The mining entrepreneur advances money $(\mathrm{M})$ to procure machines, energy, inputs and labour-power needed to extract gold from inside the earth. But if the entrepreneur in the textile industry, for example, also needs to buy cotton to transform into fabric, the miner extracts the final use value (gold = money) directly from Nature, without 
consuming any intermediary raw material. Being the product of the miners' work, gold contains surplus-value in itself.

Adapting to euros the exercise by Marx in Chapter 17 of Volume II lets us consider a capital of 500,000 euros invested in gold mining with a five-week turnover and a working period (production) of four weeks (Figure 3).

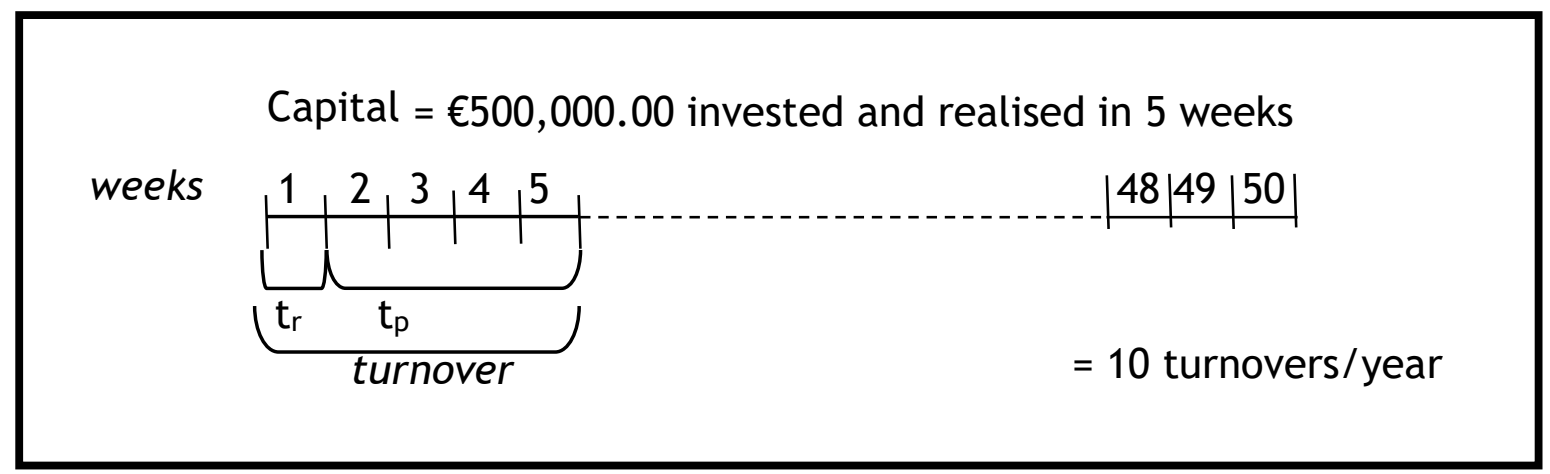

Figure 3: Money (metal) turnover

Every sixth week, $€ 600,000$ of gold produced ( $€ 500,000+€ 100,000$ of plus-value) flows back in. But that $€ 600,000$ is immediately money. That is, to buy labour-power and inputs again, the mining entrepreneur did not have to 'take' $€ 600,000$ from other entrepreneurs, selling them a commodity in return (with surplus-value added). The mining entrepreneur extracted the $€ 600,000$ from the land itself. The $€ 500,000$ that would be spent on inputs and labour-power for production $\left(t_{p}\right)$, is then replaced, with added surplus-value, with no other exchange (except with Nature...). That is, gold as money enters the general circulation of capital through the back door, through the market that provides labour-power, equipment, energy and other inputs to the miner $\left(t_{r}\right.$ in Figure 3), not the market that procures commodities (...P... $\Delta C-\Delta M)$. Therefore, money goes out (gold) without equivalent money coming in (gold). That is why, at the end of 50 weeks, or 10 turnovers, six million euros will be produced in pure gold: "this money thrown into circulation is not withdrawn from it again by the circuit which this capital describes, but is rather increased by quantities of gold constantly produced anew" (Marx 1956, 200). Surplus-money $(\Delta M)$ was created directly from the work of producing money ( = gold) without selling any new commodity $(\Delta C)$ to third parties. This difference will cover the addition of surplus-value in the whole system. The same logic applies to variable capital remuneration and to workers' consumption: wages are paid with part of the gold directly produced.

In gold mining we have a situation where there is production of value without producing a new intermediary commodity to be transformed into surplus-money. In this case, the commodity is money itself. The formula for the circulation of money (=gold) production will be, according to Marx (1956/1885, 199): 


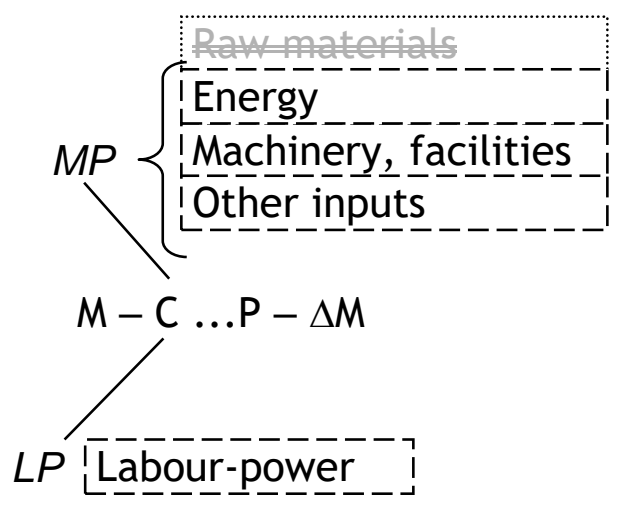

Formula 3

\section{Capital Circulation}

For capital, in its evolution and worldwide expansion, "the annihilation of space by time becomes an extraordinary necessity", Marx states in the Grundrisse (1973/1939, 449). In order to reduce the time required for the transposition of space, the capital is invested in developing means of transportation and communication:

But there are certain independent branches of industry in which the product of the productive process is not a new material product, is not a commodity. Among these only the communications industry, whether engaged in transportation proper, of goods and passengers, or in the mere transmission of communications, letters, telegrams, etc., is economically important. [...] However, what the transportation industry sells is change of location. The useful effect is inseparably connected with the process of transportation, i.e., the productive process of the transport industry. [...] The useful effect can be consumed only during this process of production. It does not exist as a utility different from this process, a use-thing which does not function as an article of commerce, does not circulate as a commodity, until after it has been produced. But the exchange-value of this useful effect is determined, like that of any other commodity, by the value of the elements of production (labour-power and means of production) consumed in it plus the surplus-value created by the surplus-labour of the labourers employed in transportation. (Marx 1956/1885, 30-31; emphasis by the present author).

Therefore, Marx would say, the formula of circulation and accumulation in the transportation industry is: 


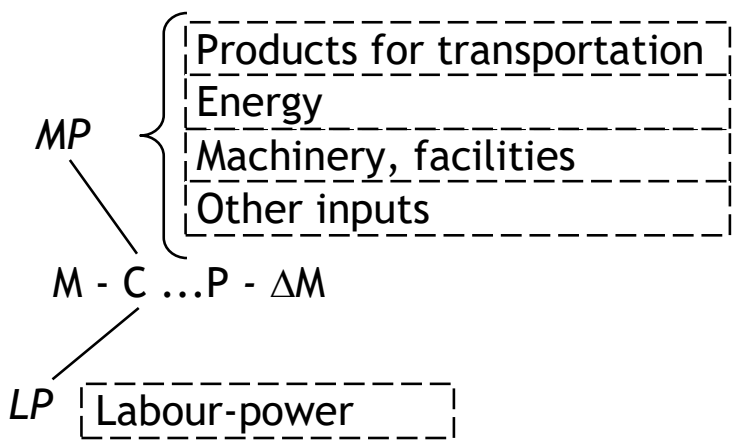

Formula 4

Marx himself comments that this formula "has almost the same form as that of the production of precious metals" $(1956 / 1885,31)$. Similar to mining, work carried out in the production of transport and communication $(P)$ is realised directly into surplusmoney $(\Delta M)$. Here, also, there is no production of new intermediary commodities. But, unlike mining, in transportation commodities from third-parties function as raw materials in some other industry: the transportation or communication entrepreneur must withdraw a commodity from circulation (in addition to equipment, energy, labourpower, etc.), transport the commodity elsewhere and then return it to circulation. Surplus value is extracted from the labour of railroad workers, seamen, truck drivers, telecommunication technicians, and so on.

The transportation company withdraws products from circulation to keep these products in circulation. This apparent contradiction is explained by the fact that the transport and communication industries comprise "a separate sphere of investment of productive capital", different because "it appears as a continuation of a process of production within the process of circulation and for the process of circulation" (Marx $1956 / 1885,88$ ). It would be as if the factory had the dimensions of its own market. If this is not possible, the opposite would be close to reality: in the huge facilities of Ford Motor Co., in River Rouge, Detroit in the 1940s, there were 160 kilometres of railways and hundreds of kilometres of conveyor belts, drawbridges and other means of transporting people and materials. ${ }^{7}$ As well as the factory, the company itself was highly vertical, trying to implement on its premises as much as possible the entire circuit $M-C \ldots P$.... Ford's goal was to reduce its production processes to circulation processes: to keep capital in permanent movement as quickly as possible.

Capital constantly seeks to reduce to a minimum the time taken for material transformation per product unit, of transportation and sale of the commodity, and of realisation of the invested capital. Therefore, it is not only a matter of cancelling spaces by time but, as shown above, also - and perhaps most importantly - reducing turnover times to a minimum or realising the highest number of possible turnovers in a year, considering that turnover time includes the time taken for production $\left(t_{p}\right)$ and realisation $\left(t_{r}\right)$. In this effort, capital developed not only efficient means of transporting commodities, but also even more efficient means of transporting information. Most of all, in the 20th century, capital expanded a powerful industry that became broadly known as 'Communications', including both its infrastructure and the production of content that adds work and surplus-value to this infrastructure (cinema, music, radio

7 "Ford River Rouge Complex", at https://en.wikipedia.org/wiki/Ford River Rouge Complex, accessed May 19, 2018. 
and television programmes, and so on). In the 21st century, the Internet arrived to join this industry. Not only to join it: in its evolution, it tends to absorb all the others.

All these industries (cinema, music, press, broadcasting radio and TV), without exception, generate a product that is not necessarily "annihilated" in its consumption: information. It is true that data storage (film, vinyl or digital disk, paper, TV sets, etc.) can be destroyed sooner or later by thermodynamic determinations. But the content remains in the minds and actions of individuals and society. It can be reproduced for eternity: today we can still read Aristotle or Virgil, whether it is on parchment, paper... or digital reader. Less than an act of consumption, the act of reading or listening is an act of reproduction (Dantas 2016; 2017): it is semiotic work (Eco 1980; Rossi-Landi 1985/1968) that social subjects perform among themselves in intersubjective interactions - not necessarily synchronous - mediated by appropriate supports. ${ }^{8}$ Throughout most of human history, the only support could be the human body itself, or papyrus and papers carried long distances by knights or sailors. From the invention of the telegraph in the 19th century, meeting the determinations of capital turnover, data storage became electronic, which allows transporting information almost at the speed of light.

Notice that in the direct processes of work and production of information and communication, there is no transformation of raw materials into new use values (cotton into fabric, for example), but productive consumption of equipment and inputs required for informational processes (machines, computers, papers, etc.). A sheet of paper, for example, receives painted forms that show letters, while still remaining a sheet of paper: it does not lose its shape or most of its original properties when it gains new communicational use value, providing the "useful effect" of transporting information. It is similar to the truck that serves the transportation circuit: even if it naturally wears out with time and work, it doesn't stop being a truck as long as it can provide the "useful effect" of transportation $(P-\Delta M)$. The general formula of the communication circuit, based on Formulas 1, 2, 3 and 4, will be Formula 5:

${ }^{8}$ By semiotic material labour, I mean any human communicational activity, according to Eco (1980) or Rossi-Landi (1985/1968): speaking-listening, reading-writing, watching TV, cinema or theatre, or representing in these media, participating in shows as an artist or as a spectator, etc. Strictly speaking, every human activity performs some kind of semiotic material work, but under the conditions of advanced capitalism this work can be directly productive or unproductive, whether or not it takes part in the production and valorisation of capital. It can also be productively paid (activities related to research and development, marketing, artistic exhibition, etc.) or productively unpaid, as audience, according to Dallas Smythe (1977) and Fuchs (2012a; 2012b). To further clarify this point, see Dantas (2001; $2011 ; 2016$; 2017). 


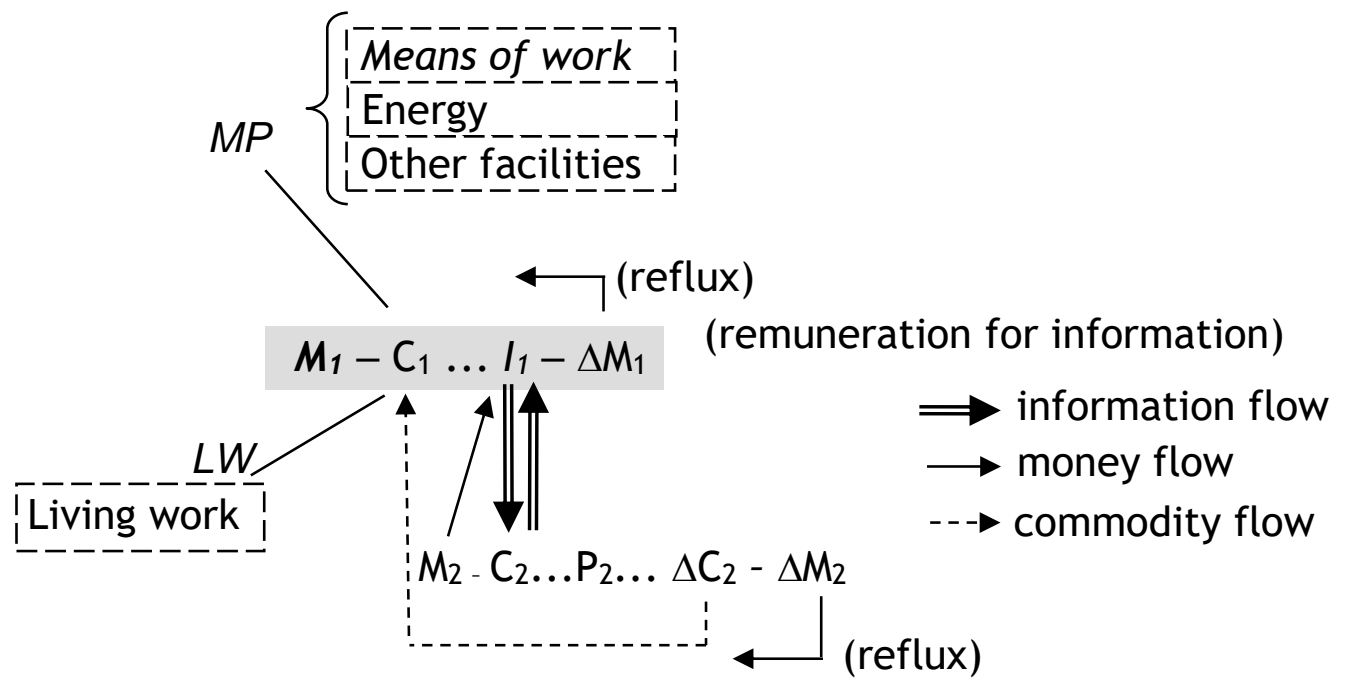

Formula 5

In the circuit $M_{1}$ there are companies or business departments specialising in employing work in the fields of technology development, marketing, promoting shows, etc., that is, information work $\left(I_{1}\right)$. The products of this work are semiotic materials: texts, images, mathematical formulas, drawings, and so on. These results are communicated by suitable media (phone lines, paper reports, computer networks, etc.), to companies or business departments that specialise in transforming the physicochemical material needed to objectify those ideas or images in machines, vehicles, clothes, food, medicines, computers, buildings, etc. (the $M_{2}$ circuit): "commodities", whether for "productive" or "unproductive" consumption. That relationship is interactive, since these firms, transformation departments or industrial assembly lines also inform them of their actual or potential offers. Hence the two-way information flow $I_{1} \leftrightarrow C_{2}$.

Information is a resource of increasing return that cannot be divided in equivalent units. In the language of the economic mainstream, information is a 'non-rival good'. In a critical language, it is a 'common' resource. Because of this, in the capitalist regime, the appropriation of the value of information is only possible by imposing monopolistic 'intellectual property rights' (IPRs) to society in the form of patents, copyrights and so on (Zeller 2008; Paulani 2016). The possession of these 'rights' allows capital to obtain informational rents to grant interested or needy parties access to forms of information they have 'protected': science, technology, artistic products, events, and so on. That is why the firms that are directly dedicated to industrial production $\left(M_{2}\right)$ remunerate the information capitalists by paying them pulpy rents for the right of access to its 'proprietary' information $\left(M_{2} \rightarrow I_{1}\right)$. The final consumers also pay these informational rents, embedded in the monopoly prices of the consumer goods they purchase. In one way or another, the 'old' Marxian cycle of goods described in Formula 5 by $\mathrm{M}_{2}$ can only keep on working, under the conditions of the informationcapital, if it agrees to pay this mandatory 'toll' to the monopolist holders of the 'intellectual property rights' - if it is not itself embedded and subsumed within any corporate holder of these 'rights' ${ }^{9}$

9 The large industrial corporations, such as Sony, Nike, Monsanto, Apple, Pfizer (to name a few striking examples), have become, in contemporary capitalism, mainly IPR producers in their laboratories of engineering and design, usually transferring the manufacturing process of production to subcontractors. In these subcontracted factories, the industrial process is 
Considering this theoretical reference, from here on, we advance to our object: sociodigital platforms. Everything said before will be used to highlight the accumulation logic of these platforms and their close links to the financial capital that funds them and draws extraordinary profits from them.

\section{Socio-Digital Platforms}

In 2017, the Internet platform market generated about USD 223.7 billion in advertising alone, excluding revenue from subscriptions, sales, etc. One third of this total was grabbed by Alphabet, the holding company that controls Google (Molla 2017). In stock exchanges, the market value of the 20 largest companies controlling these data-driven platforms reached USD 3.8 trillion in 2017 (Statista 2017).

These companies keep a tight link on financial capital, some being directly controlled by investors and speculators in equity and derivatives markets. In Facebook, 1,435 financial institutions, mutual funds or other institutional or individual investors hold $68 \%$ of the share capital. Almost $30 \%$ is in the hands of T. Rowe Price $(3.1 \%)$; Vanguard (6.4\%); FMR, LLC (5.6\%); State Street (3.9\%); Morgan Stanley (1.2\%); and Fidelity (2.17\%). ${ }^{10}$ In Alphabet, 1,701 institutions and investors hold $73.1 \%$ of the share capital. ${ }^{11}$ The dominant names, with about $28 \%$ of total capital, almost repeat themselves: T. Rowe Price (2.94\%); Vanguard (5.5\%); FMR, LLC (4.1\%); State Street (3.5\%); Capital Research (1.3\%); Fidelity (1.3\%); etc. In Amazon, 2,963 financial institutions hold $69.8 \%$ of the share capital, while T. Rowe Price, Vanguard, State Street, FMR, LCC, and Capital Research, combined, hold $22.3 \%{ }^{12}$. Similar stock profiles will be found in the other companies that control these platforms.

As marketplaces, these socio-digital platforms can be classified into three types (COM 2016; Martens 2016):

i) Market producers: those that directly aim at connecting sellers of goods or services to potential buyers, reducing turnover times and costs. Examples include Amazon, eBay, Airbnb, Alibaba, Uber.

ii) Audience producers: those aimed at connecting advertisers to a public of potential buyers. Examples: YouTube, Facebook, Instagram.

iii) Demand coordinators: those aimed at facilitating business deals, especially money transfer, between sellers and buyers. Example: PayPal.

They can also be:

i) Transactional: aimed at generating business immediately;

ii) Non-transactional: initially, most users are not interested in buying or selling goods and services (remarkable example: 'social networks').

Srnicek (2017) suggests another more refined taxonomy: advertising, cloud, industrial, product and lean platforms. He shows that the whole capitalist system, including manufacturing industries and almost all other services, is moving to different platform business models. We can realise that all these platforms, except the better-known

automated to the maximum, or performed under degrading work conditions, as is so often the case, for example, in the apparel industry where the rate of automation is still very low.

${ }^{10} \mathrm{https}$ ://finance.yahoo.com/quote/FB/holders?ltr=1, accessed May 13, 2017.

11 https://finance.yahoo.com/quote/GOOG/holders?ltr=1, accessed May 13, 2017.

12 https://finance.yahoo.com/quote/AMZN/holders?p=AMZN, accessed May 25, 2018. 
advertising platforms, are different forms of "market producers" as defined by Martens (2016). And all of them, including advertising platforms, have some basic characteristics that make them a "key business model for extracting and controlling data" (Srnicek 2017, 48).

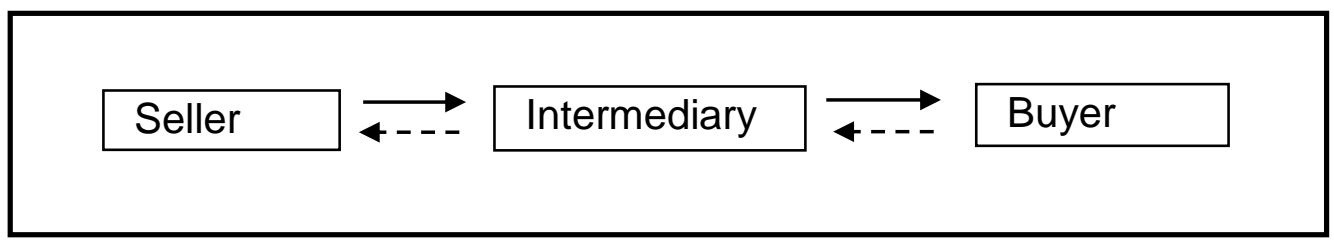

Figure 4: Unidirectional market as defined by Martens (2016)

SDPs are changing, perhaps forever, the prevailing way of doing business since the early days of modern capitalism: the producer-consumer relationship used to happen through a one-way flow of commodities, usually mediated by a salesperson. The commodity had to be moved from the factory to the store and wait there for the interest of a possible buyer (Figure 4). As we have seen, this movement led Marx to elaborate a set of exercises about capital turnover times.

SDPs provide the individual or any company with nearly immediate informational contact with a vast universe of buyers and sellers, being able to reduce transaction times to the limit of zero. They still offer the extra advantage of apparent information symmetry among the agents involved. This multilateral market brings together two large groups of users: those who sell (but can also buy) and those who buy (but can also sell). Both of them generate revenues - directly or indirectly - for the owner of the platform (Figure 5).

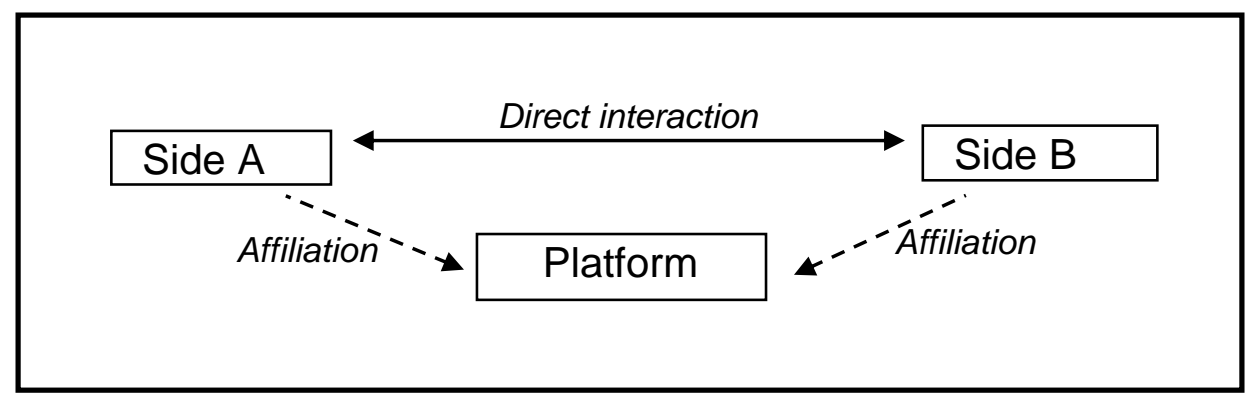

Figure 5: Multilateral networking platforms as defined by Martens (2016)

Since the SDP aims to enable individuals or groups of users to contact other individuals or groups of users, users are the primary resource of its business model. Gathering as many users as possible is what motivates investors to put money into building and maintaining these marketplaces. On the selling side, the presence of many sellers although they are competitors - helps to attract even more buyers. On the buying side, the presence of many buyers not only attracts more sellers but also increases information exchange about the price and quality of goods and services. If both selling and buying sides feel stimulated to strengthen the same marketplace, the result will be that dominant positions in the specific SDP market will be taken by those that, for some reason at a given moment, manage to display themselves as the most attractive. They benefit from the network effect: the value of the network increases with the number of 
users. And if the value increases, more users will be motivated to join (COM 2016; Martens 2016). Therefore, as we see nowadays, the worldwide platform market tends to be increasingly concentrated on and monopolised by a very small group of huge corporations: GAFA (Google/Amazon/Facebook/Apple) and a few others.

In the last decade, mobile platforms have also started expanding worldwide. Thanks to the development of 'smart' terminal devices ('smartphones') and high-speed wireless networks (3G, 4G), mobile telecommunications now account for a large share of the time people surf the Internet: between 2008 and 2015, the percentage of connected time spent on mobile devices worldwide rose from $12.7 \%$ to $54.6 \%$. By mid$2015,78 \%$ of Facebook's advertising revenue came from mobile phones (COM 2016).

Although they sometimes charge directly for their services, the main revenue source for SDPs is the 'monetisation' of their 'primary resource': the users, regardless of which side of the transaction they are on. Since browsing leaves traces that are captured in real time by the algorithms developed in the SDP owners' laboratories, these platforms hold an enormous volume of data that, when put together and articulated, provide them with complete information on the whole market in which they operate. Based on this knowledge, they benefit from their privileged position to define the rules for accessing and using their marketplaces. In other words, if the multilateral relations among users seem to hold 'Paretian' symmetry, the relationship between SDP owners and their users is, in fact, very asymmetric: only the owners really know the whole market and its further movements. From their position, they can even shape these movements (Marten 2016). However, users on any side cannot claim access to complete information about the interests and actions of millions of agents around the world: limits of space-time and of the tools available for them can narrow their decisions down to just a few sections of the whole marketplace.

The market expansion coordinated and driven by SDP owners is already changing the practical, subjective relationship that users have with the Internet and its apparently endless potentialities. The open and free search that finds what it needs on any website is being replaced by the offer that reaches the user more or less like a package, suggested as 'interesting' for them because many others have already said it is 'interesting'. 'Best records', 'best movies', 'best books', 'best restaurants', 'most important' news, the 'best' or 'most important' as defined by... the market. The user seems to be the source of the market but it is impossible to ignore the role of algorithms that process the total information in the configuration of that market. 


\section{Socio-digital platform business scheme}

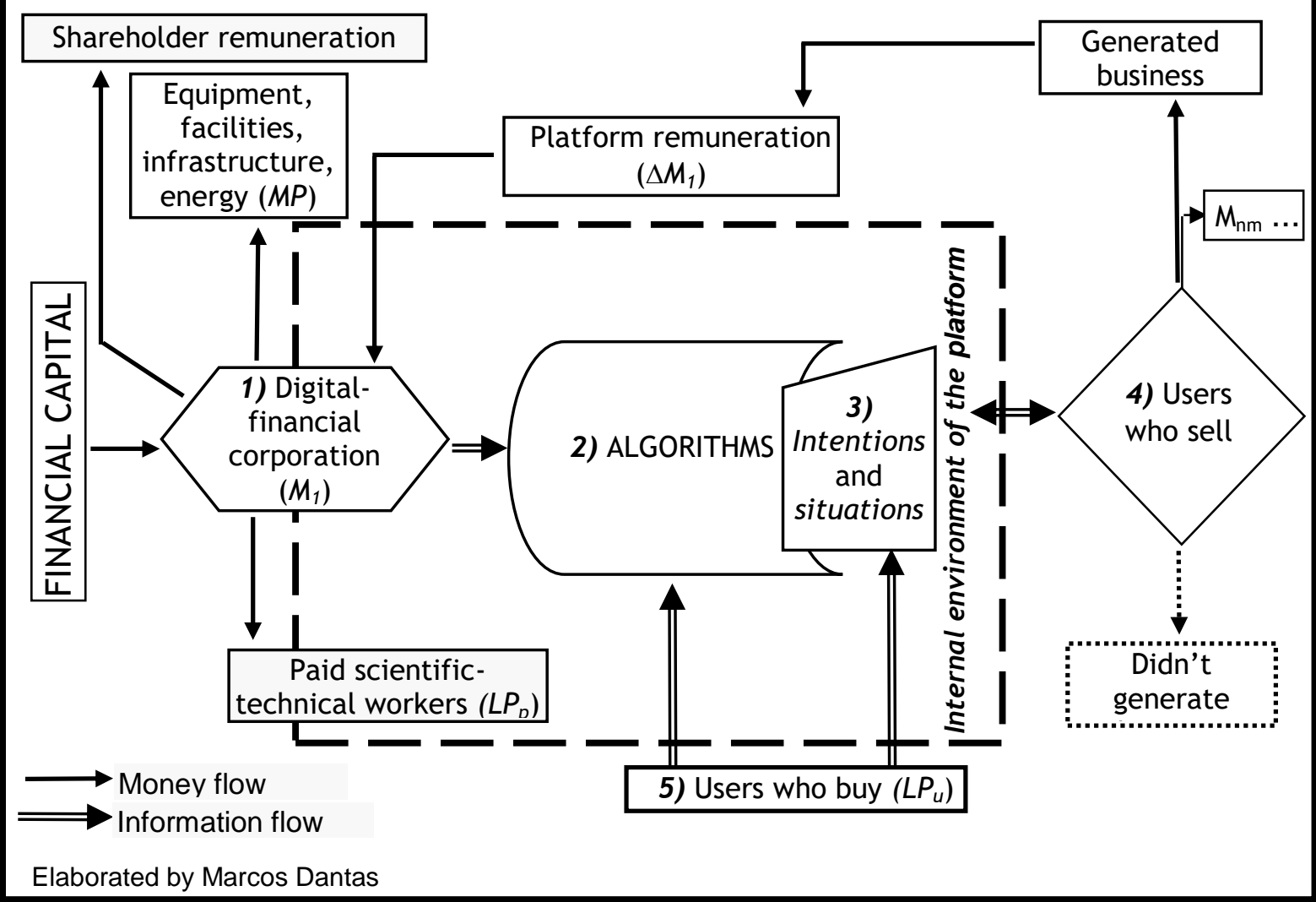

Figure 6: Socio-digital platform business scheme

Based on information that can be obtained from the websites of the main platforms, testimonials from agents of this market and from literature, the business model of these platforms can be described by the diagram in Figure 6: ${ }^{13}$

1) A corporation that is financed and supported by financial capital (such as Alphabet/Google, Facebook, Amazon, or Airbnb) advances money $\left(M_{1}\right)$ to invest in equipment, infrastructure, energy (MP) and labour-power ( $\left(P_{p}\right)$ : it withdraws commodities from circulation to consume them in their turnover circuits.

2) Algorithms are developed and controlled by contracted and paid technical scientific work to collect, analyse, organise, record and communicate data provided by millions or billions of company and individual users.

3) Sellers and buyers constantly provide not only general data about their activities and interests, but also intentions or daily life situations (possible imminent travel, a gift for the boyfriend or girlfriend, current location, etc.).

4) The seller users are individuals or companies that offer products or services (from manufactured products and services to, for example, a private apartment for rent). They also provide algorithms with their general profile data, their intentions or

${ }^{13}$ See https://www.facebook.com/business/help/1619591734742116?helpref=faq content\#, accessed on May 25, 2018;

https://www.facebook.com/business/help/430291176997542?helpref=faq content\#, accessed on May 25, 2018; https://www.youtube.com/watch?v=1C0n 9DOlwE, accessed 05/25/2018; Pearlstein (2009). 
circumstantial situations (offers), including payment limits in an auction system that defines the offer that will show up on the initial screen of a potential buyer.

5) The buyer users are thousands or millions, even billions, of companies or individuals who constantly feed algorithms with their general data, their intentions, or circumstantial situations, with no initial interest in doing business (on platforms that are audience producers) or trying to meet a demand for goods or services (on platforms that are market producers).

The algorithm has to identify and converge a buyer's intention with that of the sellers competing amongst themselves in the marketplace. The seller remunerates the platform if (i) its ad is viewed for a while on some of the thousands of screens; (ii) its ad is 'clicked' by someone, opening its website on the screen of the person who clicked it; (iii) by the period of time the author(s) of the 'click' browses its website; (iv) by effectively closing a business deal; (iv) other factors. The algorithm controls all this. No transaction should be made out of the platform. Profile data or user intentions are not provided, much less sold, to customers, except for some secondary business deals. In general, customers can receive statistical data on their sites' success rates (number of clicks, visits, closed deals, etc.), but initially they will not receive profile data about groups, much less about individuals, in their own marketplace. ${ }^{14}$

Of course, sellers constitute many other circulation circuits $M_{n}-C_{n} \ldots P_{n} \ldots \Delta C_{n}-$ $\Delta M_{n}$ or $M_{m}-C_{m} \ldots P_{m}-\Delta M_{m}$, depending on their economic sector (manufacturing, retail, finance, agriculture, myriads of services, and so on). For this user category, the "useful effect" (in Marx's words) of the socio-digital platform is that it allows them to drastically reduce their turnover times, while proportionally reducing the faux frais. The latter is possible due to the direct and almost individual interaction with potential buyers provided by the marketplace. Particularly, in some cases, the money circuit time is detached from the (various) product circuit times. The money circuit can be realised in seconds: SDPs have definitely replaced metal or paper currency with electronic currency in a digital form that can be transported almost at the speed of light by telecommunication systems. In the one-way business model (Figure 4), SDPs would need to wait for the buyer to visit the store to sell the commodity $(\Delta C)$ and receive the corresponding money $(\Delta M)$ at the same time. Money would still need to flow backwards, probably through a bank, to its original investor. This movement has considerably accelerated after the launch of debit and credit cards. In the multilateral model (Figure 5), the buyer makes a decision based on the image of the commodity or service on the screen and transfers money to the seller almost instantly through credit card, PayPal or similar platforms. But if you acquire a commodity that has physicochemical mass and volume you may have to wait a few days or weeks to receive it at home or work. The realisation time ( $t_{r}$ in Figures 1 and 2 ) could be drastically reduced, with money almost immediately entering the financial circuit, although, from the final consumer's viewpoint, the product may still remain in the seller's stock for a few days or take some time to be shifted by means of transportation.

${ }^{14}$ The origin of the Cambridge Analytica scandal was the revelation that the company had access to the private data of thousands of people. Neither the company nor anyone else was supposed to have access to such data. With these very accurate data in its possession, Cambridge Analytica drew up successful political electoral strategies for its clients. The company obtained the data through a researcher with access allowed by Facebook, who believed he was only interested in doing academic research under ethical confidentiality reservations (Llano and Sanchez 2018; Bejerano 2018). 
In case of semiotic use value turnover (music, books, movies, videogames, etc.) or many services that now drive the capitalist economy (tourism and hotels, for example), the substitution of physicochemical currencies by digital-form electronic currencies practically reduces to the limit of zero the realisation times $\left(t_{r}\right)$ of the money circuit and often that of the product circuit.

To make all this possible, the corporations that control SDPs hire scientifictechnical work $(L P p)$ to develop and continually analyse and improve algorithms. Most of this work is of a scientific-technical nature and well remunerated. But if the platform business also involves stocking and moving goods that have physicochemical volume and mass, their worldwide labour-power may include, as in the case of Amazon, more than 300,000 low-paid workers in warehouses and transport. At the other extreme, the WhatsApp platform employs only 50 engineers.

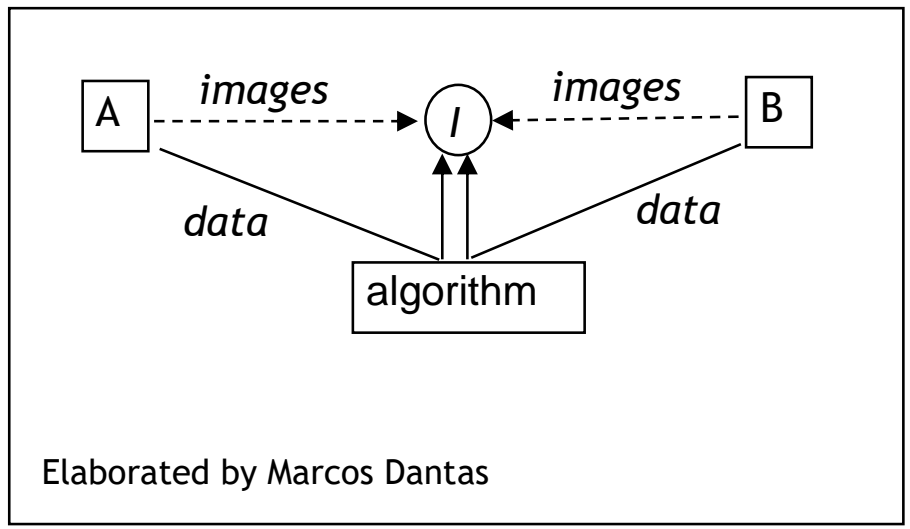

Figure 7: Information transport in SDPs

Algorithms are for SDPs as machines are for factories: fixed capital. To generate and feed them, SDPs withdraw energy, inputs and living work from circulation but do not return commodities into circulation: the data permanently produced through algorithms are not supplied to the 'market', as a commodity coming out of machines would be. Data fuel the platform, or rather, its algorithms, just as energy fuels factory machines or cargo ships. Through data, sellers' and buyers' intentions and situations can be connected in a time reaching the limit of zero, as they are viewed (as images) on computer or mobile phone screens. The platforms transport information while connecting sellers and buyers. As stated above, this is the "useful effect" they produce. This effect will be more useful the more the turnover times - more precisely the realisation times - of the sellers can be minimised. Platforms can do this by transporting from seller $(A)$ to buyer $(B)$ - and vice versa - the information $(I)$ produced with the data of both users, at rates of gigabits per second, in a way that can be twoway or convergent (Figure 7).

Developed and permanently observed, improved and analysed by paid work $\left(L P_{p}\right.$ in Figure 6), algorithms would not carry out their information transport functions if they were not being constantly fed with seller and buyer profile data, intentions and situations. Just as machines need to be connected to a power source, algorithms need to be connected to an information source. This is why users should keep themselves in almost constant activity. In this 21 st century, for reasons that refer to commodity fetishism (research on which is beyond the scope of this article), capitalist society is forced to remain in constant electronic activity, turning it into a nearly vital cultural need, 
such as food or clothing. Since it has become a social need, interactive activity on SDPs, especially on audience producer platforms, is no longer free: it is culturally compulsory. As Fuchs $(2012 b, 638)$ states, this population acting on SDPs is under "ideological coercion (they are compelled to use the platforms of dominant corporations in order to keep their social relations and reputations. If they stop using these platforms, they won't die or get killed, but they will feel more isolated)". In order to still fit into this society, this population is subjectively obliged to acquire a fixed or mobile access terminal, to subscribe to a broadband service and, above all, to stick to the unilateral and extortionate rules of SDPs: extortionate because in exchange for apparently free or very cheap services the users have to give up their privacy. ${ }^{15}$

So, this becomes a work situation. As Robert Heilbroner (1988) explains, work, in its economic and sociological concepts, is understood as an activity that aims to meet a compulsory need, happening under conditions that let some take hold of resources that others need in order to work. Generally, in capitalist societies, this activity is remunerated in some way. But within the information-capital that owns the resources of socio-digital platforms, the work of feeding the algorithms is often unpaid: users receive nothing for the data they provide and some of them, as in the case of the sellers, even pay (subscription, advertising, fees, etc.) to benefit from its "useful effects". While they dialogue with words, sounds and images - that is, semiotic material - about their 'desires', 'likes', 'joys', 'sorrows', 'rages', 'dreams', 'knowledge', and their 'income', 'health', 'education', etc., users productively consume the algorithms of the platforms and the devices they use to access them (fixed or mobile terminals) just like the workers in a factory productively consume their machines and their own labourpower. This is not about the final consumption that "annihilates" the commodity. Users provide unpaid labour for a certain amount of time ( $\mathrm{LP}_{\mathrm{u}}$ in Figure 6) that can be equivalent to all the time they spend interacting on platforms: that is, almost all day except (for now) the hours of sleep. Surplus-value 2.0...

The general formula for circulation on socio-digital platforms would be, as a rule, the same as that used for transport: $M-C \ldots P-\Delta M$, in which $P$ is a process of production and transport of information that directly produces surplus-money rather than new commodities. However, considering its particularities as a means of producing and transporting information, as described here, the general formula will be:

15 The appropriation of other people's privacy by SDPs became so invasive that public authorities began to worry about this matter. While this article was being written, European Union countries had just adopted the General Data Protection Regulation, designed to regulate the relationship between SDPs and their users. 


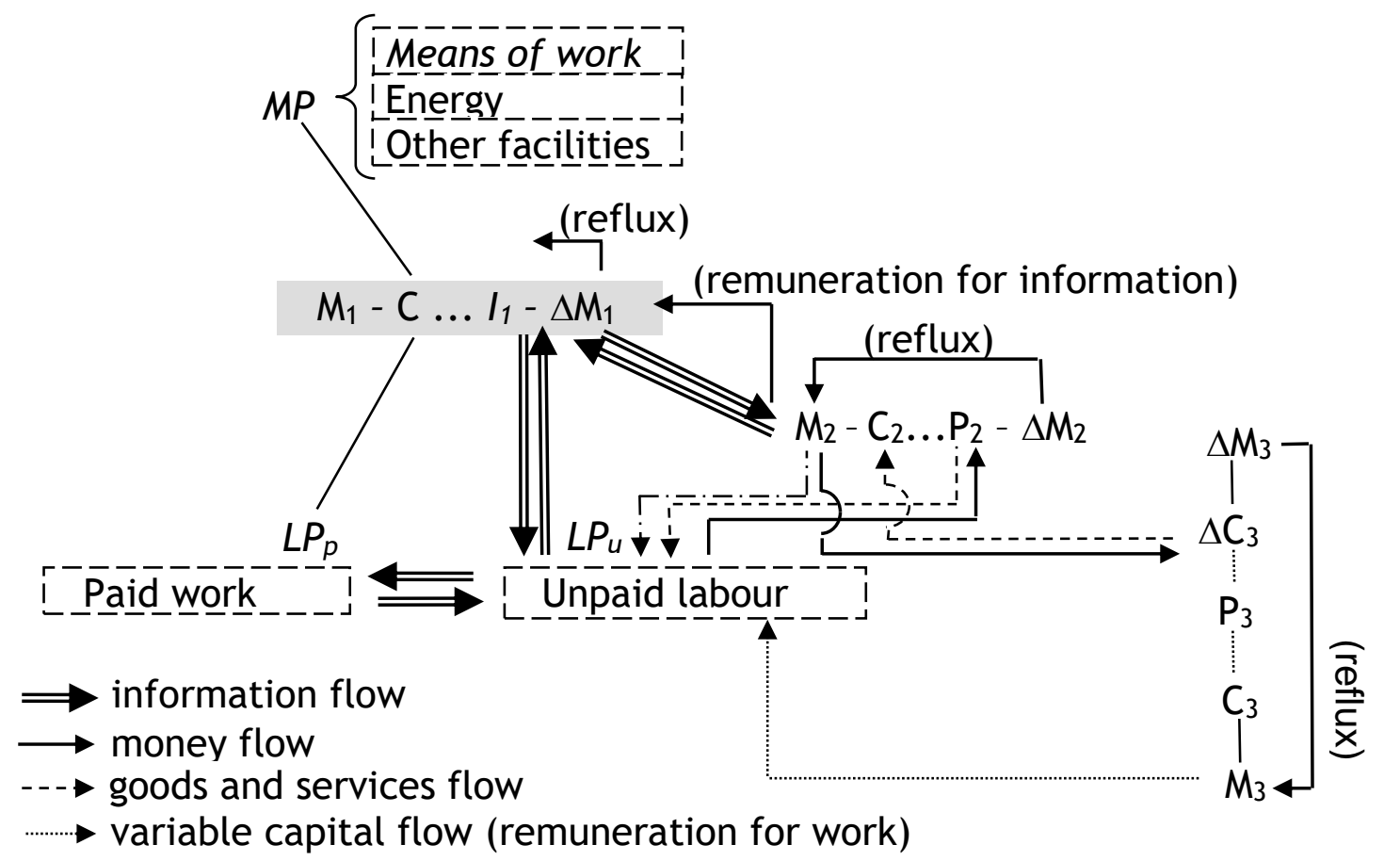

Formula 6

The shareholders of socio-digital platforms advance money $M_{1}$ to procure means of production MP and remunerated (scientific-technical) work LPp to process information (algorithms) extracted basically from unpaid labour LPu which, after all, is the entire global society connected to the Internet by fixed or mobile terminals. The informationvalue $I$ is related, inside the platform, with the other market agents: here, we will differentiate the intermediary level $\mathrm{M}_{2}$ and the level of real commodity producers $\mathrm{M}_{3}$. Trade, tourism, mass media, consulting firms, lawyers, advertising agencies and other services can be considered producers and communicators of information-value. On one hand, the large connected population works for the SDPs; on the other, it procures its goods and services mainly from the circuit $\mathrm{M}_{2}$ : dashed arrow (goods and services) $P_{2} \rightarrow L P_{u}$ and continuous arrow (money) $L P_{u} \rightarrow P_{2}$. The hired and wage-earning labour in $P_{2}$ will directly produce plus-money $\Delta \mathrm{M}_{2}$ in this specific information cycle (usually called 'services').

Besides the advances it naturally makes for means of production and labour-power $\left(C_{2}\right)$, the capital represented by $M_{2}$ also invests money in advertising and other communications that feed the platform's algorithms: hence the two-way information flows $I_{1} \leftrightarrow M_{2} \ldots \Delta M_{2}$ and the one-way money flow $M_{2} \rightarrow M_{1} \ldots \Delta M_{1}$, remunerating the platform capital.

The means of production expressed by $C_{2}$ that are required for the $P_{2}$ process are procured by $M_{2}$ from a third level $M_{3}$ in which the physicochemical transformation that produces supports for the entire informational circuit occurs: shops sell clothes, restaurants sell food and beverages, tourism requires aeroplanes and buildings built of concrete and glass, and every great mass media spectacle event needs sports arenas, as well as television receivers and physical telecommunication networks. Capital $\mathrm{M}_{3}$ still operates according to the "old" logic exposed by Marx in the first pages of Volume II. It is the origin of the commodities that will support the whole process $\left(\Delta C_{3}\right.$ $\left.\rightarrow C_{2}\right)$. And it is also the destination of part of the surplus-value extracted by $M_{2}$ in 
its own turnover and money reflux circuits $\left(M_{2} \rightarrow \Delta C_{3}\right)$. We should recall, as aforementioned, that at this level the production processes are highly automated and subsumed within the informational living work of scientific-technical research, project, design, marketing, etc., also implemented in $M_{2}$.

The work of society that is unpaid by SDPs is naturally paid by $M_{2}$ and $M_{3}$ (in Formula 6, "variable capital flow"). Of course, the speed of turnover and the realisation of variable capital will also be positively affected by the SPD circuit. On the other hand, in addition to remunerating SDPs for the 'service' of annihilating space by time or exponentially multiplying the quantity of annual turnovers, productive capital also provides financial support - through wages or other forms of remuneration - to the general work of society that feeds and valorises the platforms at no cost. Financial capital, that - as we know - grabs part of the surplus-value extracted by productive capital through interest on loans, found in SDPs another powerful way of seizing the surplus-value of social labour - here, with no intermediaries. And it sends the bill to those who actually produce...

We have seen, in the production of gold as money, the mining firm put money back into circulation without producing any intermediary commodity: with the labour of the miners, it extracts the value and surplus-value contained in the gold as money (moneycommodity) from a common resource of the society - the soil or subsoil -which it appropriated as private propriety under the blessing of the capitalist State laws. Because, in Marx's words, gold or silver mining did not put valued commodity $(\Delta C)$ back into circulation in exchange for plus-money $(\Delta M)$, this production originated the imbalance throughout the process of circulation and accumulation that, nevertheless, is essential to the continuing growth of the whole capitalist system. Now we can see that SDPs are producing money-commodity in the same way as in the past gold or silver mining: they mine data in the commons of society employing general intellect unpaid labour.

Data, like any other form of information, cannot be exchanged. This is not to say that there is not a tradable market of data, but this market is operated inside the algorithms under rules that only algorithms (or their builders) really know. Sellers and buyers insert their data in algorithms endeavouring to provide the best answer they can to demands or desires of both user sides. If someone wants to buy flowers, he or she will have access to the necessary data about flower shops (types of flowers, prices, delivery time, quality and reliability of the service as attested to by other buyers, etc.). And the seller, too, shops with the necessary data about the customer to whom they sold a bouquet of flowers (name, address, etc.), and may also have access to other data that inform about their own trading results through the platform (clicks, visits to the site, etc.) in order to improve their competitive strategies in this seemingly 'Paretian' informational marketplace.

Both user sides have access to the use value of data appropriated and monopolised by the platform, but the price paid by the seller to the platform for its 'service' does not express any exchange value, only the quantum of money the 'market' has agreed to pay circumstantially in these auctions. In several passages of Capital, Marx argues that goods or services may have a price without having value: it is sufficient that they can be monopolised by a party and that there is another party interested in buying them. This is typical in the case of the art market or the money market. The price, in such cases, results from chance settlement between the parties. And, when he explained the money market (Capital: Volume 3, Part 5), Marx also noted that this "commodity sui generis" can be borrowed without its ownership actually being transferred from the "seller" (the banker) to the "buyer" (the industrial or trader): 
"Ownership is not relinquished, because there is no exchange and no equivalent is received" (Marx 1959/1894, 228). The borrower of the loan, as we well know, is obliged to return the money plus interest after a certain time. The economic logic of market data is similar. Because of the informational nature of data, the ownership of its use value may not be transferred; it can only be accessed, just as in the case of money from the bank: the loan is nothing more than access by the borrower to an amount of money strictly held by the financier but necessary for the production of real value by productive capital. The profit extracted from this operation is rent. ${ }^{16}$

Algorithms are 'protected' by patents and other IPRs. But to prevent possible copying and reproduction at almost zero cost due to the increasing returns of information, algorithms and their data are also protected by a business model referred to as the "walled garden" in business literature (see, for example, Marsden et al. 2006). This means the imposition of access to platforms solely through strictly-controlled telecommunications networks (owned by private corporations) and terminal devices designed to take complete control over user activities (smartphones, smart TVs, ereaders, videogames consoles and so on). ${ }^{17}$ The name "walled garden" is a perfect metaphor, relating to the process of land enclosure of British fields in the early stage of modern capitalism. We are living today in a new enclosure process - the enclosure of knowledge and all cultural or social practices of human society by data-driven platforms.

The relationships, including similarities, between the data market and the money market indicate a vast field of more advanced investigations. From the data mined from the common culture of society through users' unpaid labour time, to the monetisation of these data, via access, without real exchange of equivalent values $(I-\Delta M$ circuit), the economic logic of the SDPs seems to be located at the financial level of the circulation of capital. Furthermore, the surplus-value of the SDPs feeds the financial market in an extraordinary way. Through the immediate data transformation into electronic currency, SDPs bring back to circulation (by the 'back door', as for the $\mathrm{gold} /$ money mine in the past) the refluxed plus-money $\left(\Delta M_{1} \rightarrow M_{1}\right)$ that will replace or procure new means of production, pay salaries and stipends of hired workers and, above all, generously remunerate the shareholders in the stock market. In 2016, Alphabet/Google distributed USD 19.5 billion to shareholders, representing $21.6 \%$ of its gross revenue or $82.1 \%$ of its operating revenue (gross revenue minus pre-tax deductions) that year. The distributed profit was much higher than the costs for research and development (USD 13.9 billion) and sales and marketing (USD 10.5 billion), including expenditure with the work of its scientists, engineers, and so on. ${ }^{18}$ In

${ }^{16}$ Investigating the business model of Google, Lee (2011) draws similar conclusions. Access to advertising space in the Google's environment is only possible by auctions of keywords but, notes Lee, the advertiser who tenders the winning bid does not become "owner" of the keyword. He does not take the word home, so to speak, as we can take a painting purchased in an art auction. Keywords are forms by which information contained in data is released to the advertiser by the algorithm. As information, its "ownership" cannot be transferred, but can be shared.

${ }^{17}$ Revenues and profits of the mass media also constitute rent extracted from advertisers due to the control that the media holds on the electronic or printed channels for access to the public, as Caraway (2011) states in an article in which he discusses Dallas Smythe's hypothesis.

${ }^{18}$ Alphabet Inc. Annual Report, Form 10-K, fiscal year finished on December 31, 2016, available at https://abc.xyz/investor/pdf/20171231 alphabet 10K.pdf, accessed June 18, 2018. 
2015, Facebook distributed USD 3.7 billion in profits to shareholders, which represented $20.6 \%$ of its gross revenue or $59.2 \%$ of its operating revenue. ${ }^{19}$ Amazon distributed USD 2.4 billion, $17.4 \%$ of its gross revenue or $56.6 \%$ of its operating revenue.$^{20}$ Just like other platforms, these are real money-making machines... ${ }^{21}$

\section{Conclusions}

As seen before, in the capitalist process of accumulation according to Marx, there may exist circuits in which the process of labour and production of value directly results in surplus-money $(\Delta M)$, not intermediated by a commodity-value $(\Delta C)$. One of these circuits is that of communication, or the production and transportation of information. Capital has unleashed a plethora of businesses designed to narrow the time periods of realisation of investments by stimulating consumption and even an entire society moved by spectacle and commodity fetishism, in terms of a wide and diverse literature that includes Bourdieu (1979), Debord (1977/1967), Fontenelle (2002), Schneider (2015) and others.

On this sociocultural basis, (financial) capital is able to work in its ideal quintessence: in the market where circulation times seem to reach the limit of zero. It is a market that does not depend on the circulation time of a commodity: once it is bought, if it has physicochemical mass and volume (clothes, furniture, vehicles, machines), it may take a few days to make its way to the buyer's hands. If it is semiotic material, such as music, film or an e-book, it will be delivered in a few seconds. In either case, the financial transaction has already been concluded in a shorter time than a commercial one would be. At the same time, financial capital can 'look' at the entire market, from which it obtains exclusive and total information, whereas other agents only obtain segmented information, often oriented by the 'preferences' of so-called 'consumers' processed by the algorithms of socio-digital platforms. Capital is the network.

We realise that all the capitalist logic described in this article demonstrates the permanence of the law of value in this new stage of information-capital. But just as the effects of the law of gravity are not exactly the same on the surface of the earth and the moon, so the effects of the law of value can change to the extent that economic or social conditions change within the historical evolution of capitalism. This does not change the foundation of the law: the accumulation of capital is a function of surplus (unpaid) labour. At the same time, capital operates by continuously undermining or eliminating necessary (paid) labour. It needs to posit this to have that, but also needs to reduce this to increase that. Therefore, if it releases work in an industry to the extent

${ }^{19}$ Facebook Annual Report, Form 10-K, fiscal year finished on December 31, 2015, available at http://www.getfilings.com/sec-filings/160128/Facebook-Inc 10-K/, accessed May 13, 2017.

${ }^{20}$ Amazon.Com Inc. Annual Report Form 10-K, fiscal year finished on December 31, 2016, available at http://phx.corporate-ir.net/phoenix.zhtml?c=97664\&p=irolsec\&control selectgroup=Annual\%20Filings, accessed June 24, 2018.

${ }_{21}$ The close relationship between the SDPs and financial capital is also investigated by Nick Srnicek (2017). He argues that the low profitability of investments in industry and in many services has pushed financial capital to investments that were much more profitable on the Internet. 'Loose' monetary policies reducing the interest of the public securities also helped trigger the search for investments that were shown to be much more profitable in the dotcom companies. In the period 1980-1990, billions of dollars were channelled to the development and expansion of businesses, which would eventually converge on the huge platforms that, from the second decade of the 21 st century, tended to dominate the Internet. 
that it raises its organic composition, it increases work in another, as a condition in fact to open new frontiers of investment, accumulation and expansion. Moving in this dialectic, it should not be surprising that capital is reaching a stage of such widespread commodification of social life that it has come to incorporate almost all of the population in the process of production of surplus-value (unpaid surplus labour), extending the process of valorisation and accumulation in addition to the direct relations of employment where they still survive by necessary (paid) labour. The surplus-value of the unpaid labour absorbed by the SDPs is sustained, as we have seen, by the variable capital of other circuits of money and production. Thus, contrary to what Marx would have imagined, the reduction of the general intellect of society into surplus labour in the form of compulsory informational semiotic activities on the screens of computers and smartphones, or, in other words, the appropriation by capital of the disposable time of society, seems to have been the main result of the achievement by capital, pressed by law of value, in eliminating the large amount of redundant labour that, during Fordism, it still needed to employ in factories, offices, banks, and in other economic activities. The commodity with mass and volume may have been replaced by the image of the commodity, as Debord anticipated, but unpaid labour, the source of surplus-value, is increasingly being extended to almost all the time and space of human life in this highly connected network society.

Marx wrote:

The more the metamorphoses of circulation of a certain capital are only ideal, i.e., the more the time of circulation is equal to zero, or approaches zero, the more does capital function, the more does its productivity and the self-expansion of its value increase (Marx 1956/1885, 73).

And Marx did not know about the Internet...

\section{References}

Arvidsson, Adam and Eleanor Colleoni. 2012. Value in Informational Capitalism and on the Internet. The Information Society 28 (3): 135-150.

Bejerano, Pablo G. 2018. O Facebook já não tem o controle do que acontece com os dados dos usuários', diz ex-diretor. El País, 7/05/2018. Accessed May 26, 2018. https://brasil.elpais.com/brasil/2018/05/04/tecnologia/1525422138 239714.html.

Bourdieu, Pierre. 1979. La Distinction: Critique Sociale du Jugement. Paris: Les Editions de Minuit.

Caraway, Brett. 2011. Audience Labor in the New Media Environment: A Marxian Revisiting of the Audience Commodity. Media, Culture \& Society 33 (5): 693-708.

Chen, Chih Hsien. 2003. Is the Audience Really Commodity? An Overdetermined Marxist Perspective of the Television Economy. Annual Meeting of the International Communication Association, San Diego, California.

COM 2016: European Commission. 2016. Online Platforms Accompanying the document Communication on Online Platforms and the Digital Single Market, $\{\operatorname{COM}(2016) 288$ final $\}$ Brussels: European Commission. Accessed May 5, 2019. https://ec.europa.eu/digitalsingle-market/en/news/commission-staff-working-document-online-platforms

Dantas, Marcos. 2017. Information as Work and as Value. tripleC: Communication, Capitalism \& Critique. Open Access Journal for a Global Sustainable Information Society. 15 (2): 816-847. Accessed April 17, 2017. http://www.marcosdantas.com.br/conteudos/2017/11/19/information-as-work-and-as-value

Dantas, Marcos. 2016. Media Spectacle and the Appropriation of Creative Labour by Information-Capital. In Gouvernance et Service Public Médiatique dans les Sociétés de la 
Connaissance - Actes du Colloque, edited by Gaëtan Tremblay and Anne-Marie Brunelle, 26-42. Montreal: Cricis-UQAM. Accessed July 17, 2018.

http://marcosdantas.com.br/conteudos/2017/02/13/the-media-spectacle-and-theappropiation-of-creative-labour-by-information-capital/

Dantas, Marcos. 2011. Internet abierta vs "jardines amurallados": el libre acceso al conocimiento y las artes en disputa. Herramienta 47: 19-29. Accessed July 17, 2018. https://www.herramienta.com.ar/articulo.php?id=1484

Dantas, Marcos. 2001. L'Information et le travail: la valorisation et l'accumulation dans le cycle de la communication productive. In Vers un capitalisme cognitif: entre mutations du travail et territoires, edited by Christian Azaïs, Antonella Corsani and Patrick Dieuaide. Paris: L'Harmattan.

Debord, Guy. 1977/1967. The Society of Spectacle. Marxists Internet Archive [website]. Accessed August 27, 2017: https://www.marxists.org/reference/archive/debord/society.htm.

Eco, Umberto. 1980. Tratado geral de Semiótica. São Paulo: Perspectiva.

Fontenelle, Isleide. 2002. O nome da marca: McDonald's, fetichismo e cultura descartável. São Paulo: Boitempo.

Fuchs, Christian. 2012a. Dallas Smythe Today: The Audience Commodity, the Digital Labour Debate, Marxist Political Economy and Critical Theory. Prolegomena to a Digital Labour Theory of Value. tripleC: Communication, Capitalism \& Critique. Open Access Journal for a Global Sustainable Information Society 10 (2): 692-740.

Fuchs, Christian. 2012b. With or Without Marx? With or Without Capitalism? A Rejoinder to Adam Arvidsson and Eleanor Colleoni. tripleC: Communication, Capitalism \& Critique. Open Access Journal for a Global Sustainable Information Society 10 (2): 633-645.

Garnham, Nicholas. 1990. Capitalism and Communication. London: Sage

Harvey, David. 2013. A Companion to Marx's Capital, Volume II. London: Verso.

Heilbroner, Robert L. 1988. Behind the Veil of Economics. New York: W. W. Norton.

Huet, Armel, Jacques Ion, Alain Lefèbvre, Bernard Miège and René Peron. 1978. Capitalisme et industries culturelles. Grenoble: Presses Universitaires de Grenoble.

Jhally, Sut and Bill Livant. 1986. Watching as Working: The Valorisation of Audience Consciousness. Journal of Communication 36 (3): 122-142.

Lee, Mike. 2011. Google ads and the blindspot debate. Media, Culture and Society 33 (3): 433-447.

Llano, Pablo de and Álvaro Sánchez. 2018. Vazamento de dados do Facebook causa tempestade política mundial. El País, 20/03/2018. Accessed May 26, 2018. https://brasil.elpais.com/brasil/2018/03/19/internacional/1521500023 469300.html,

Marsden, Chris et al. 2006. Assessing Indirect Impacts of the EC Proposals for Video Regulation. Santa Monica: CA Rand Corporation. Accessed August 26, 2017. https://www.rand.org/content/dam/rand/pubs/technical reports/2006/RAND TR414.pdf

Martens, Bertin. 2016. An Economic Policy Perspective on Online Platforms, JRC Technical Report. European Commission. Accessed May 13, 2017. https://ec.europa.eu/jrc/sites/jrcsh/files/JRC101501.pdf

Marx, Karl. 1973/1939-41. Grundrisse: Foundations of the Critique of Political Economy. London: Penguin Books/New Left Review, HTML markup by Andy Blunden (2002) and Dave Allinson (2015). E-book conversion by Dave Allinson (2015). Accessed July 22, 2018. https://www.marxists.org/archive/marx/works/download/pdf/grundrisse.pdf

Marx, Karl. 1959/1894. Capital: A Critic of Political Economy, Vol. III, transcribed by Hinrich Kuhls, Dave Walters and Zodiac, and by Tim Delaney and M. Griffin (1996-1999). Moscow: Progress Publishers. Accessed January 29, 2019. https://www.marxists.org/archive/marx/works/download/pdf/Capital-Volume-III.pdf

Marx, Karl. 1956/1885. Capital: A Critic of Political Economy, Vol. II, transcribed by Doug Hockin and Marxists Internet Archive in the Philippines (1997), proofed and corrected by Andy Blunden and Chris Clayton (2008), Mark Harris (2010). Moscow: Progress 
Publishers. Accessed July 22, 2018.

https://www.marxists.org/archive/marx/works/download/pdf/Capital-Volume-II.pdf

Maxwell, Richard. 1991. The Image is Gold: Value, the Audience Commodity, and Fetishism. Journal of Film and Video 43 (1-2): 29-45.

Molla, Rani. 2017. Google Leads the World in Digital and Mobile Ad Revenue. Recode, 24/07/2017. Accessed May 7, 2018. https://www.recode.net/2017/7/24/16020330/googledigital-mobile-ad--revenue-world-leader-facebook-growth

Paulani, Leda Maria. 2016. Acumulação e rentismo: resgatando a teoria da renda de Marx para pensar o capitalismo contemporâneo. Revista de Economia Política 36 (3): 514-535.

Pearlstein, Joanna. 2009. Anatomy of an Auction. Wired, 23 February 2009. Accessed May 27, 2018. https://www.wired.com/2009/02/anatomy-of-an-auction/

Rossi-Landi, Ferruccio. 1985/1968. A linguagem como trabalho e como mercado. São Paulo: Difel.

Schneider, Marco. 2015. Dialética do gosto. Rio de Janeiro: Circuito.

Smythe, Dallas W. 1977. Communications: Blindspot of Western Marxism. Canadian Journal of Political and Social Theory 1 (3): 1-27.

Srnicek, Nick. 2017. Platform Capitalism. Cambridge: Polity Press.

Statista. 2017. Market Capitalization of the Biggest Internet Companies Worldwide as of May 2017 (in billion US dollars). Accessed May 9, 2018.

https://www.statista.com/statistics/277483/market-value-of-the-largest-internetcompanies-worldwide/

Zallo, Ramón. 1988. Economía de la comunicación y de la cultura. Madrid: Akal.

Zeller, Christian. 2008. From the Gene to the Globe: Extracting Rents Based on Intellectual Property Monopolies. Review of International Political Economy 15 (1): 86-115.

\section{About the Author}

\section{Marcos Dantas}

Marcos Dantas is Professor at the Communication School of the Federal University of Rio de Janeiro (ECO-UFRJ). He holds a doctorate (DSc) in Industrial Engineering from COPPEUFRJ. He is a researcher in the Communication and Culture Postgraduate Program at ECOUFRJ and in the Information Science Postgraduate Program at IBICT/ECO-UFRJ. He is also a member of the Brazilian Internet Steering Committee (CGI.br). He was also Planning and Budget Secretary of the Brazilian Ministry of Communication, the Distance Education Secretary of the Brazilian Ministry of Education, and a member of the Consultative Commission of the National Telecommunications Agency. He is also a member of the Executive Board of Celso Furtado International Centre for Development and former President of the Latin Union of Information, Communication and Culture - Brazilian Chapter (ULEPICC-Br). Professor Dantas' most important books are A lógica do capital-informação (1996), Trabalho com informação (2012), and Comunicações, Desenvolvimento, Democracia (2013). 